\title{
Late Holocene Hydro-Climate Variability in the Eastern Mediterranean: A Spatial Multi-Proxy Approach
}

\author{
Dimitrios Bassukas (D), Alexandros Emmanouilidis and Pavlos Avramidis* (D) \\ Department of Geology, University of Patras, 26504 Patras, Greece; dhbassukas@gmail.com (D.B.); \\ alex.emman@upatras.gr (A.E.) \\ * Correspondence: p.avramidis@upatras.gr
}

check for

updates

Citation: Bassukas, D.;

Emmanouilidis, A.; Avramidis, P.

Late Holocene Hydro-Climate

Variability in the Eastern

Mediterranean: A Spatial Multi-Proxy

Approach. Water 2021, 13, 3252.

https://doi.org/10.3390/w13223252

Academic Editors: Serafeim E. Poulos,

Vasilios Kapsimalis and Ioannis

P. Panagiotopoulos

Received: 28 September 2021

Accepted: 14 November 2021

Published: 17 November 2021

Publisher's Note: MDPI stays neutral with regard to jurisdictional claims in published maps and institutional affiliations.

Copyright: (c) 2021 by the authors. Licensee MDPI, Basel, Switzerland. This article is an open access article distributed under the terms and conditions of the Creative Commons Attribution (CC BY) license (https:/ / creativecommons.org/licenses/by/ $4.0 /)$.

\begin{abstract}
A total of thirteen (13) paleoclimatic coastal and hinterland archives of the broader eastern Mediterranean region were collected and examined statistically in search of underlying trends for the period 2800 to 200 BP. For each archive, a proxy record representative of hydro-climatic changes was selected, normalized using z-factors to facilitate intercomparison, and analyzed statistically. Multivariate statistical analysis was performed using a clustering analysis (HCA) and dimension reduction (PCA), which led to groupings of similar records temporally, and allowed the identification of spatially underlying modes of variability. Two main modes of variability were identified, further supporting complex trajectories of paleoclimatic evolution in the region. The first mode was identified for sites presenting a trend from a wetter to an overall drier phase, with respective changes at major phase shifts at $1400 \mathrm{BP}$ and $1100 \mathrm{BP}$. All sites were from the southern and northern Balkan region, as well as southwestern Turkey. A contrasting dry to wet trend was identified for a site in the Peloponnese (Greece) and the Levant, with a major phase shift at around 750 BP. The inclusion of different proxies from very different environmental settings and the 200-year window has complicated the connection of established short-term climatic events to the study's findings.
\end{abstract}

Keywords: z-scores; coastal records; lake records; proxy synthesis; paleoclimate

\section{Introduction}

Global climate change in the last decades has been a hot topic for geoscientific research and public discussion alike, mainly around human-induced warming. With this warming being unambiguously attributed to anthropogenic greenhouse emissions, quantifying it, making projections, as well as preparing for future change have brought up major challenges. The ultimate goal has been the establishment of future scenarios that can successfully assess the natural as well as social, political, and economic impacts around the globe [1].

The dissimilar effect [2] and heterogeneity of climate change in different regions have emphasized the need for regional assessments. In this regional context, the Mediterranean has been characterized as a climate change "hot-spot" [3,4], with an urgent need for adaption to its effects [5,6]. Specifically, for the eastern Mediterranean region, which is the area of interest in this study, current warming is projected to result in a severe decrease in precipitation [7].

Instrumental observations of the climate system hardly cover the last two centuries; therefore, the understanding of climate variability has to complementarily rely on reconstructions of past climates [8,9]. Past efforts have led to a dense network of such reconstructions in the circum-Mediterranean and the eastern Mediterranean more specifically $[10,11]$. Synthesizing the existing data has divulged spatial and temporal variability with dominant south-east versus north-west dipoles throughout the basin's Holocene paleoclimatic evolution [12-14]. This evolution has been roughly divided into three phases: a humid phase from the early Holocene until $7000 \mathrm{BP}$, an intermediate transitional period 
from 7700 to $5500 \mathrm{BP}$, and aridification from $5500 \mathrm{BP}$ onwards [15,16]; however, a concise and holistic understanding for the eastern Mediterranean and the whole basin has been very difficult, even more so in the late Holocene. With an increasing amount of information, it is even more imperative to identify trends and fit variability into a temporal context $[10,11,17,18]$.

The main aim of this study is to investigate and detect spatial and temporal patterns underlying the very complex climatic variability in the eastern Mediterranean for roughly the last 2800 years. Potentially, results from this study can provide invaluable aid in future climatic studies and solid ground for the disentanglement of climate dynamics in this climatically forced region.

\section{Materials and Methods}

In this study, the archives used were lagoon/lake sediments and cave speleothems. Basic criteria for accepting or rejecting several candidate archives are in some accordance with those in the review by [11] and are: (a) a well-established chronology with at least one measurement for every 200 years and one accepted dating for every 2000 years; (b) a temporal range covering the period from 200 to $2800 \mathrm{BP}$. Availability of the data is a major parameter in the number of final sites.

For the intercomparison of archives, a single proxy was used for each study. As hydroclimatic variability was the mean of comparison, only proxies reflecting hydro-climate were chosen. The selection of one representative proxy for each site, indicating wetter/drier conditions, was made mostly based on the interpretations of the original studies.

The comparison of unevenly sampled disparate archives was tackled by resampling the sequences into bins of equal time intervals $[11,17,18]$. A 200-year interval was chosen as a representative time period covering important hydro-climatic change, which has been used in similar [11] and pollen-based studies in the Mediterranean [19,20]. For each 200-year bin, all proxy measurements corresponding to that interval were averaged, yielding a single representative value. In the period of interest (2800 to 200 years), this led to 14 bins representing each archive. Temporal coverage sites with only one empty bin, containing no measurement in 200 years, were accepted, and with more than one rejected. If the missing bin covered the last 200 years (200 BP to present, with present being 1950), the bin was left empty; otherwise, the value was calculated averaging the previous and next bin.

To compare proxies of different environmental sensitivity, the use of z-scores was implemented. In each sequence, the proxy series mean for $2800 \mathrm{BP}$ to present was subtracted from the binned value and then divided by the standard deviation of the sequence. Through this, all proxies were normalized with 0 as the mean and the standard deviation as the measurement unit of distance, and therefore variability, from the mean. Positive z-scores were associated with a relatively drier signal from the proxy, and negative z-score values with wetter signals, respectively. To ensure consistency among the datasets, in some cases z-scores were multiplied with $(-1)$ if a wetter period was represented by positive values and vice versa. The interpolation at intermediate intervals, in time, ultimately filters the high-frequency variation and therefore blurs any short-term events with a duration smaller than the bin's. Short, extreme events can disproportionally affect a bin, resulting in a false interpretation for the 200-year interval.

To detect similar temporal fluctuations, a hierarchical cluster analysis was performed on the z-score normalized data (Table S1). For the dissimilarity measure, the Spearman distance was chosen. A correlation-based distance was used as the grouping was based on overall fluctuations regardless of magnitude; in this case, positive z-scores (a dry signal) and vice versa. For the intercluster dissimilarity and the dendrogram, the average linkage was used.

Following the methodology in [17], we strived to find a composite record for each cluster in the hope of being representative of a temporal trend and useful as a means of comparison to the subsequent PCA. Within each cluster, an average z-score was calcu- 
lated for every 200-year interval period, resulting in a single representative record for the whole cluster.

Lastly, principal component analysis was used to infer trends in our data. The principal components representing the majority of variance in the data were used together with the cluster composites in determining trends underlying the proxy variability. A total number of 13 archives were considered in the present study and are presented in Table 1.

Table 1. All sites used in the analysis, with the chosen hydro-climatic proxy and reference to the original studies.

\begin{tabular}{|c|c|c|c|c|c|c|c|c|}
\hline ID & $\begin{array}{l}\text { Altimeter } \\
\text { (m.a.s.1.) }\end{array}$ & Site Name & Lon & Lat & Proxy & $\begin{array}{l}\text { Mean Sampling } \\
\text { Interval (Years) }\end{array}$ & $\begin{array}{l}\text { Dating } \\
\text { Technique }\end{array}$ & Reference \\
\hline 1 & 0 & Gialova lagoon & 21.671 & 36.963 & $\delta \mathrm{D}_{31}$ & 74 & ${ }^{14} \mathrm{C}$ & {$[21]$} \\
\hline 2 & 0 & Lake Lerna & 22.729 & 37.580 & $\delta \mathrm{D}_{23}$ & 60 & ${ }^{14} \mathrm{C}$ & [22] \\
\hline 3 & 2 & Aliki salt pond & 23.047 & 38.198 & $\begin{array}{c}\text { PC (Ter. } \\
\text { Elements) }\end{array}$ & 3 & ${ }^{14} \mathrm{C}$ & {$[23]$} \\
\hline 4 & 11 & $\begin{array}{c}\text { Lake } \\
\text { Trichonida }\end{array}$ & 21.552 & 38.571 & $\mathrm{Rb} / \mathrm{Sr}$ & 1 & ${ }^{14} \mathrm{C}$ & {$[24]$} \\
\hline 5 & 0 & Lake Butrint & 20.031 & 39.786 & $\mathrm{Ti} / \mathrm{Ca}$ & Subannual/annual & $\begin{array}{l}{ }^{14} \mathrm{C} / \text { Laminae } \\
\text { counting }\end{array}$ & {$[25]$} \\
\hline 6 & 690 & Lake Ohrid & 20.712 & 41.041 & $\delta^{18} \mathrm{O}$ & 37 & ${ }^{14} \mathrm{C} /$ tephra & [26] \\
\hline 7 & 140 & Lake Doiran & 22.751 & 41.221 & $\mathrm{~K}$ & 4 & ${ }^{14} \mathrm{C}$ & [27] \\
\hline 8 & 1060 & Lake Cubuk & 30.834 & 40.482 & $\delta^{18} \mathrm{O}$ & 38 & ${ }^{14} \mathrm{C}$ & [28] \\
\hline 9 & 260 & Sofular cave & 31.963 & 41.446 & $\delta^{13} \mathrm{C}$ & 13 & U-Th & [29] \\
\hline 10 & 950 & Lake Gölhisar & 29.598 & 37.115 & $\delta^{18} \mathrm{O}$ & 95 & ${ }^{14} \mathrm{C}$, tephra & {$[30,31]$} \\
\hline 11 & 340 & Jeita cave & 35.640 & 33.943 & $\delta^{18} \mathrm{O}$ & 11 & U-Th & {$[32]$} \\
\hline 12 & -216 & Lake Kinneret & 35.580 & 32.811 & $\delta^{18} \mathrm{O}$ & 55 & ${ }^{14} \mathrm{C}$ & [33] \\
\hline 13 & 680 & Soreq cave & 35.022 & 31.756 & $\delta^{18} \mathrm{O}$ & 16 & U-Th & [34-36] \\
\hline
\end{tabular}

\section{Results}

\subsection{Clusters}

Using hierarchical clustering analysis, all sequences were attributed to three distinct clusters based on their long-term variation (Figure 1). Each cluster consists of sites with temporally similar patterns of relatively wetter $(-)$ or drier $(+)$ periods, according to the z-score-transformed data. For each cluster, a composite sequence is presented, representing the mean trend throughout the cluster in time (Figure 1).

The first cluster includes four ( $\mathrm{n}=4$ ) sites: (1) Gialova lagoon [21], (8) Lake Cubuk [28], (11) Jeita cave [32], and (12) Lake Kinneret [33]. The averaged time series (composite series) for the first cluster indicates drier periods from 2800 to $2600 \mathrm{BP}$, a less dry and closer to the mean period from 2600 to $2200 \mathrm{BP}$, and an increase in relatively drier conditions reaching the cluster's maximum from around 1400 to 1200 BP. From 1200 to 800 BP, a stable, less dry climate is followed by transition to a wetter period from 800 to $200 \mathrm{BP}$. The composite is characterized by an overall drier to wetter trend (Figure 2)

The second cluster includes two $(n=2)$ sites: (2) Lake Lerna [22] and (13) Soreq cave [34-36]. The averaged time series for this cluster indicates wetter conditions relative to the mean from 2800 to $2600 \mathrm{BP}$, more dry conditions from 2600 to $2400 \mathrm{BP}$, and considerably drier conditions from 2400 to 1800 BP. From 1800 to 1000 BP, wetter conditions are apparent, with the wettest period of the composite being from 1600 to $1400 \mathrm{BP}$. From 1000 to $800 \mathrm{BP}$, dry conditions are evident and are followed by a considerably wetter period from 800 to $400 \mathrm{BP}$. An abrupt change to wetter conditions in the bin spanning from 600 to $400 \mathrm{BP}$ is also apparent in the first composite. In the period 400 to 200, BP a shift to a drier climate is recognized. 


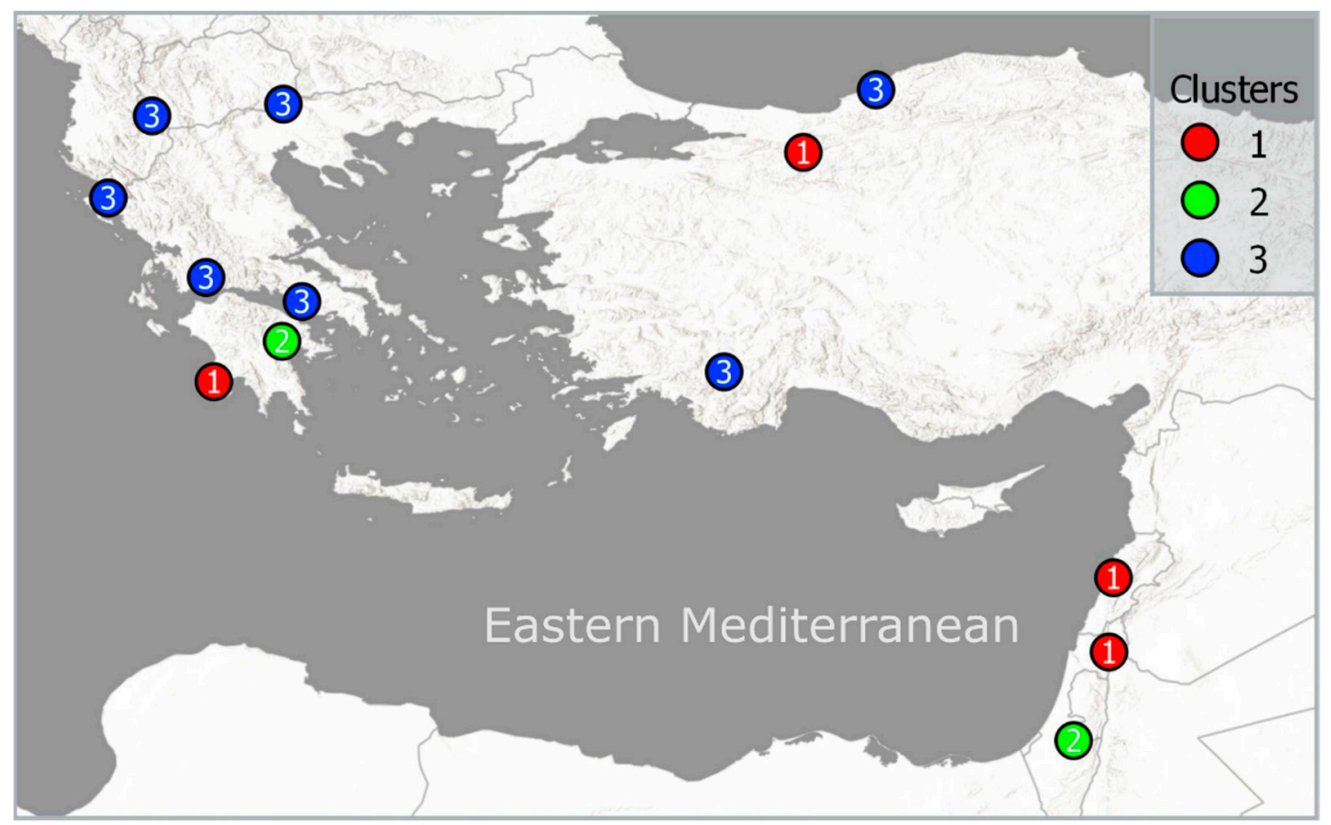

(A)

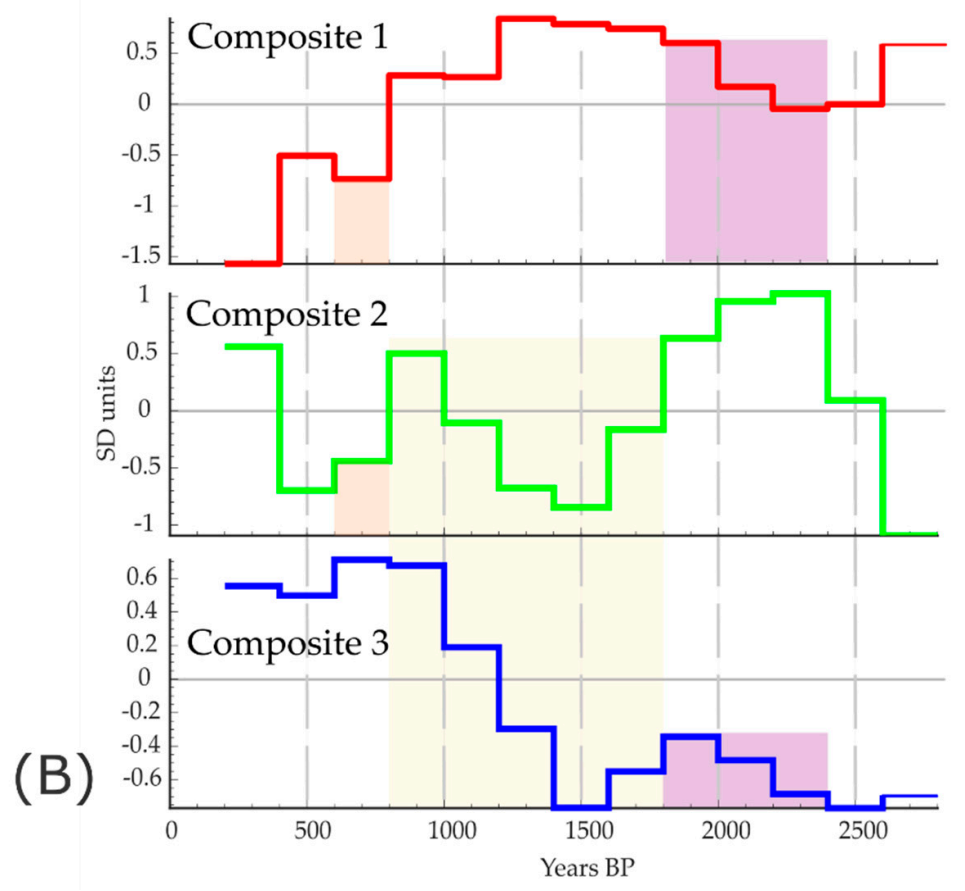

Figure 1. (A) Spatial context of the clustering; (B) composite (bin averaged) series for each cluster.

The last cluster consists of seven sites ( $\mathrm{n}=7)$ : (3) Aliki lagoon [23], (6) Lake Ohrid [26], (4) Lake Trichonida [24], (5) Lake Butrint [25], (7) Lake Dojran [27], (9) Sofular cave [29], and (10) Lake Golhisar [30,31]. From 2800 to $1200 \mathrm{BP}$, generally wetter composite mean conditions are inferred, with a considerably wetter bin from 1600 to $1400 \mathrm{BP}$. This is followed by a drier phase until 200 BP. An overall trend from relatively wetter to drier conditions is apparent for this cluster (Figure 2). 


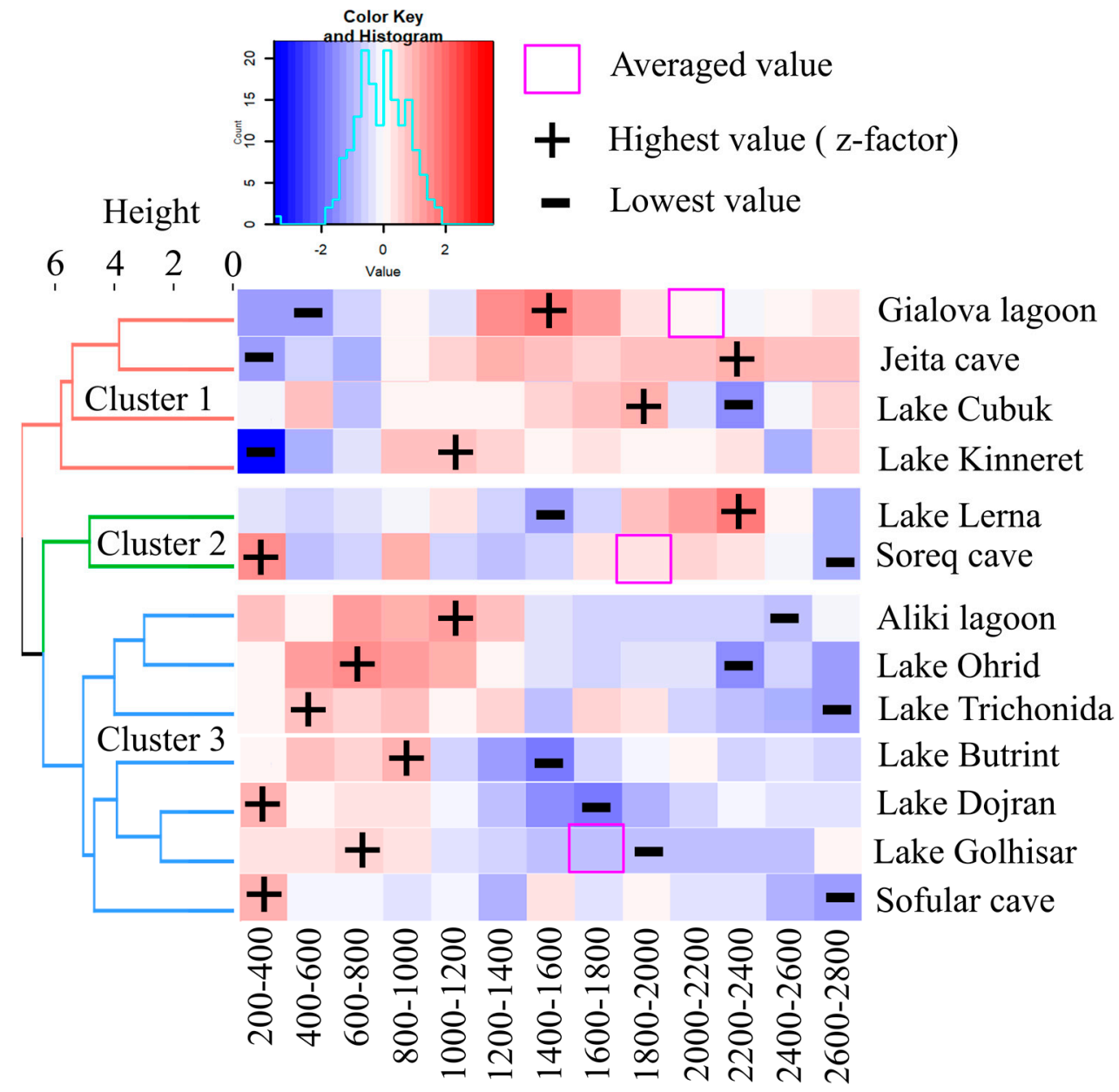

Figure 2. Heatmap of the final z-score dataset with an accompanying dendrogram. The highest and lowest (relatively drier and wetter) values are indicated with $+/-$, respectively. Periods with originally missing data are indicated by a square.

\subsection{Principal Components}

The first principal component explains $44.2 \%$ of the variation in our data. It mainly emphasizes centennial-scale trends from progressive drying followed by progressive wetting (Figure 3A). Temporally, it shows drier conditions from 2800 to $1800 \mathrm{BP}$ (Figure 3A). From 1800 to $1400 \mathrm{BP}$, even drier conditions are evident, followed by a change to overall wetter conditions from $1000 \mathrm{BP}$ onward. PC1 resembles composite 1 by contrasting an overall drier to wetter phase. This is further indicated by the coherence of sites in the first cluster presenting positive loadings with the first component (Figure 3B). A Spearman correlation test between composite 1 and the scores of the first component (Spearman $\rho=0.67, p$-value $=0.016$ ) further indicates substantial correlation.

The second principal component explains $20.1 \%$ of the variance in our dataset. PC2 emphasizes a progressive change to wetter conditions followed by a progressive drying (Figure 3A). More specifically, wetter conditions cover the period from 2600 to $2200 \mathrm{BP}$, with a drier period following for the rest of the studied record until $400 \mathrm{BP}$ (Figure 3A). Some similarity occurs with the general trend of cluster 1 , from wetter to drier. However, the loadings associated with $\mathrm{PC} 2$, and the discrepancy in the time of change from overall wet to overall dry at around 2200 to $2000 \mathrm{BP}$, point to a subcluster of cluster 3 (Aliki lagoon, Lake Ohrid, and Lake Trichonida), together with Lake Kinneret, Lake Cubuk, and Gialova (cluster 1), as well as Lake Golhisar in cluster 1 to a lesser extent (Figure 3B). Intercluster dissimilarity is therefore evident. It should also be noted that Lake Lerna, in proximity 
to Aliki, Trichonida, and Gialova, shows negative loadings, with opposite signals for the period 2600 to $2200 \mathrm{BP}$ (Figure 3B).
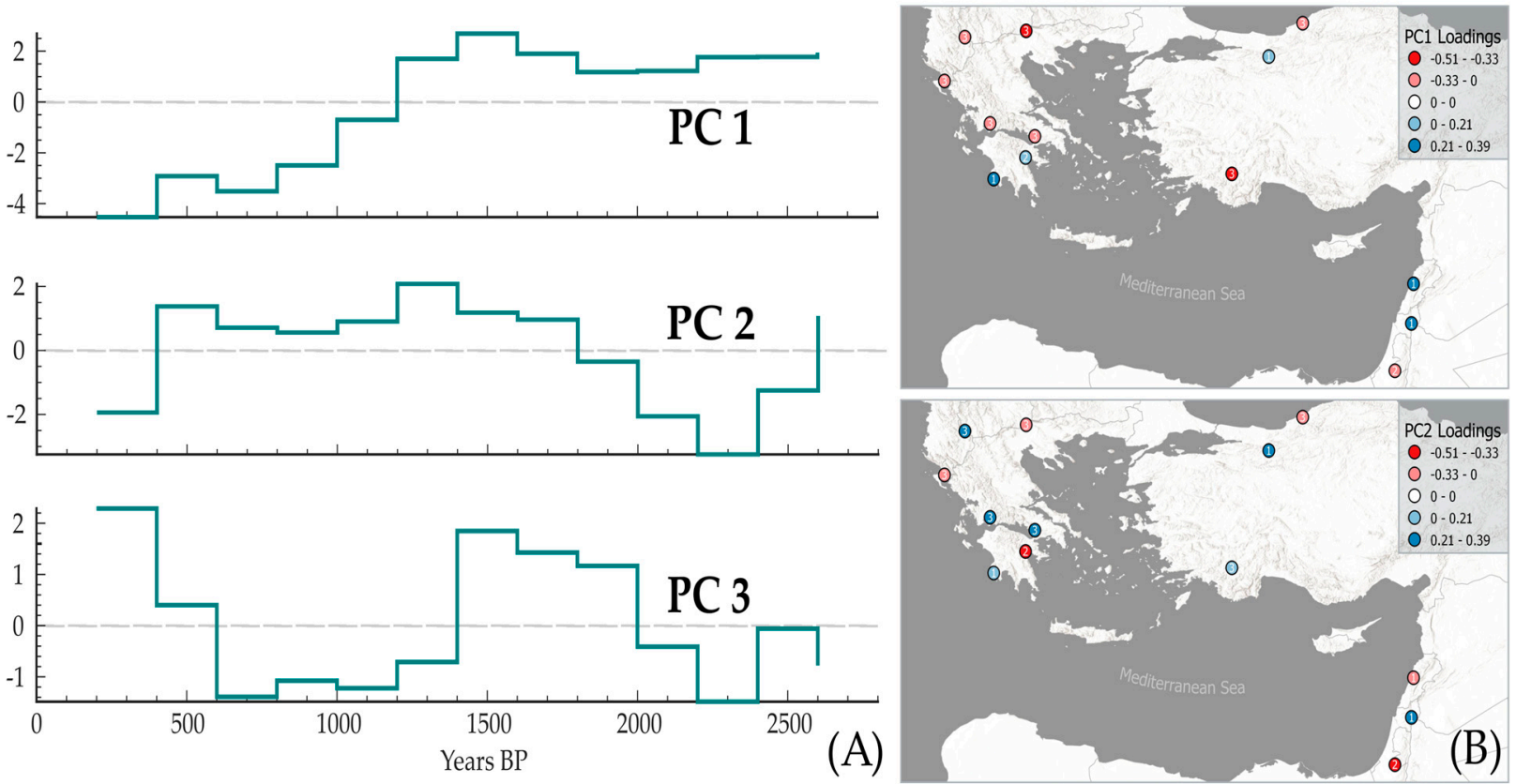

Figure 3. (A) Principal component scores against time. (B) Loadings of the 2 prime principal components.

The third principal component explains $13.6 \%$ of our data. It emphasizes a progressively drier climate from 2000 to $1400 \mathrm{BP}$ and a wetter phase from 1400 to $600 \mathrm{BP}$, followed by an increase in arid conditions thereafter (Figure 3A). This component was not further linked to our data.

\section{Discussion}

The clustering process resulted in groupings partly based on similar temporal fluctuation to the 2800-year mean in each study (z-scores with a 200-year step are presented in Figure S1). The unifying trend in the first cluster seems to be a dry to wet millennial trend with a major shift to wetter conditions at around 800 to $600 \mathrm{BP}$ (Figure 4). The studies in this cluster are spatially very distant, grouping parts of SW Greece, northern Turkey, and the northern Levant. At Gialova lagoon, overall stable warmer (2600 to 2300 BP) to increasingly drier conditions from 2000 to around 1300 BP are reported [21]. Similar aridity trends are generally inferred for the Levant until $1700 \mathrm{BP}$ and for the eastern Mediterranean in general from 2400 to $1600 \mathrm{BP}$ [10]. More specifically, at Jeita cave, the drier conditions last until 1200 BP while the 2800-1400 BP dry period is described as "a severe millennial event" [32] of the Holocene. At Lake Kinneret, the drier period extends from 2300 to 750 BP [33]. At Lake Cubuk, drier conditions are, however, indicated only until 2300 BP (Near East aridification phase) and 1600 to $1100 \mathrm{BP}$ [28], and this location therefore stands out in the cluster. Proximate Lake Iznik has extended aridification but only until 2000 BP [37]. The period following 1300 to $700 \mathrm{BP}$ is often termed as the medieval climate anomaly (MCA). This period in the Gialova record is divided into a wetter phase (1300 to $1000 \mathrm{BP}$ ) and a drier phase (until $700 \mathrm{BP}$ ). For the Levant, the MCA is characterized by wetter conditions. The period of extended drought in the cluster comes to an end with an overall shift to wetter conditions after $750 \mathrm{BP}$, coinciding with the Little Ice Age (LIA) period. Although, this is not the case for Lake Cubuk, which seems to be a misfit in this cluster. 


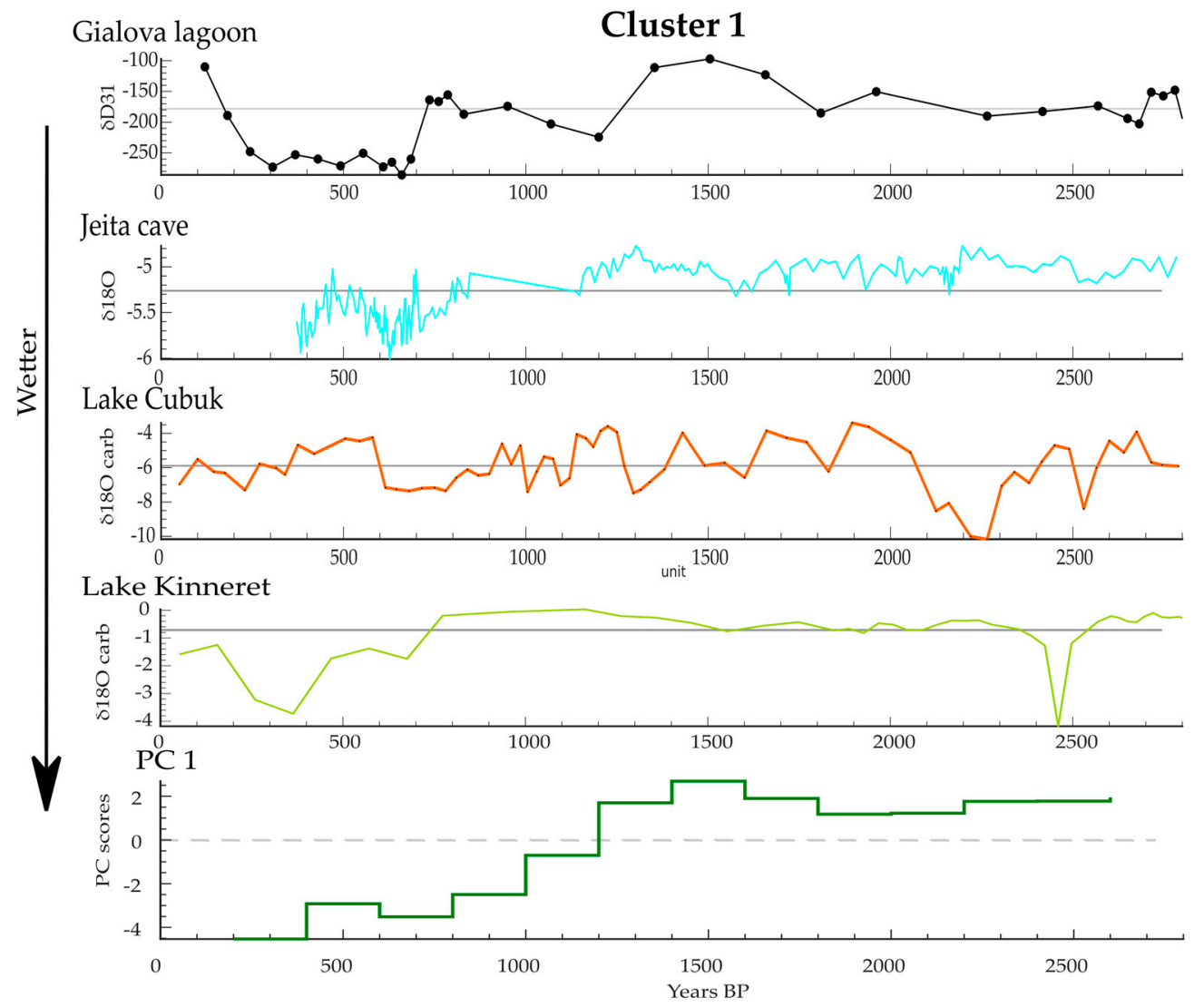

Figure 4. Original proxy records of cluster 1.

The second cluster consists of Lake Lerna [22] and Soreq cave [34-36] (Figure 5). A similarity in hydro-climatic variability among these sites has been outlined by the authors in [22] and has been successfully pointed out by the clustering process. Rather more interesting is the division of the Peloponnesian peninsula, between the first and the second cluster, and likewise of the northern and southern Levant [32]. The division of the peninsula has been attributed to changes in the North Sea-Caspian atmospheric circulation pattern (NCP) [38,39], with (+) phases leading to more precipitation in the north-eastern Peloponnese and drier conditions in the south-west and vice versa.

In contrasting states to the first cluster and an intermediate second, the sites in the third cluster present a trend from wetter to overall drier conditions (Figure 5). The sites in this cluster geographically cover the southern Balkans (except the Peloponnese) and northern and south-western Turkey, contrasting the first cluster and resembling a northsouth/east-west seesaw in the region. PC2, Lake Trichonida [24], Lake Ohrid [26], and Aliki Lagoon [23] are similar and show intercluster variability. In the same manner, similarities are shown between Lake Butrint [25] and Lake Dojran [27] and to a lesser extent Sofular cave [29] and Lake Golhisar [30]. For the first three sites, an overall wetter phase shifts to broader drier conditions around $1400 \mathrm{BP}$, whereas for the other sites in the cluster, this transition happens at around $1100 \mathrm{BP}$. 

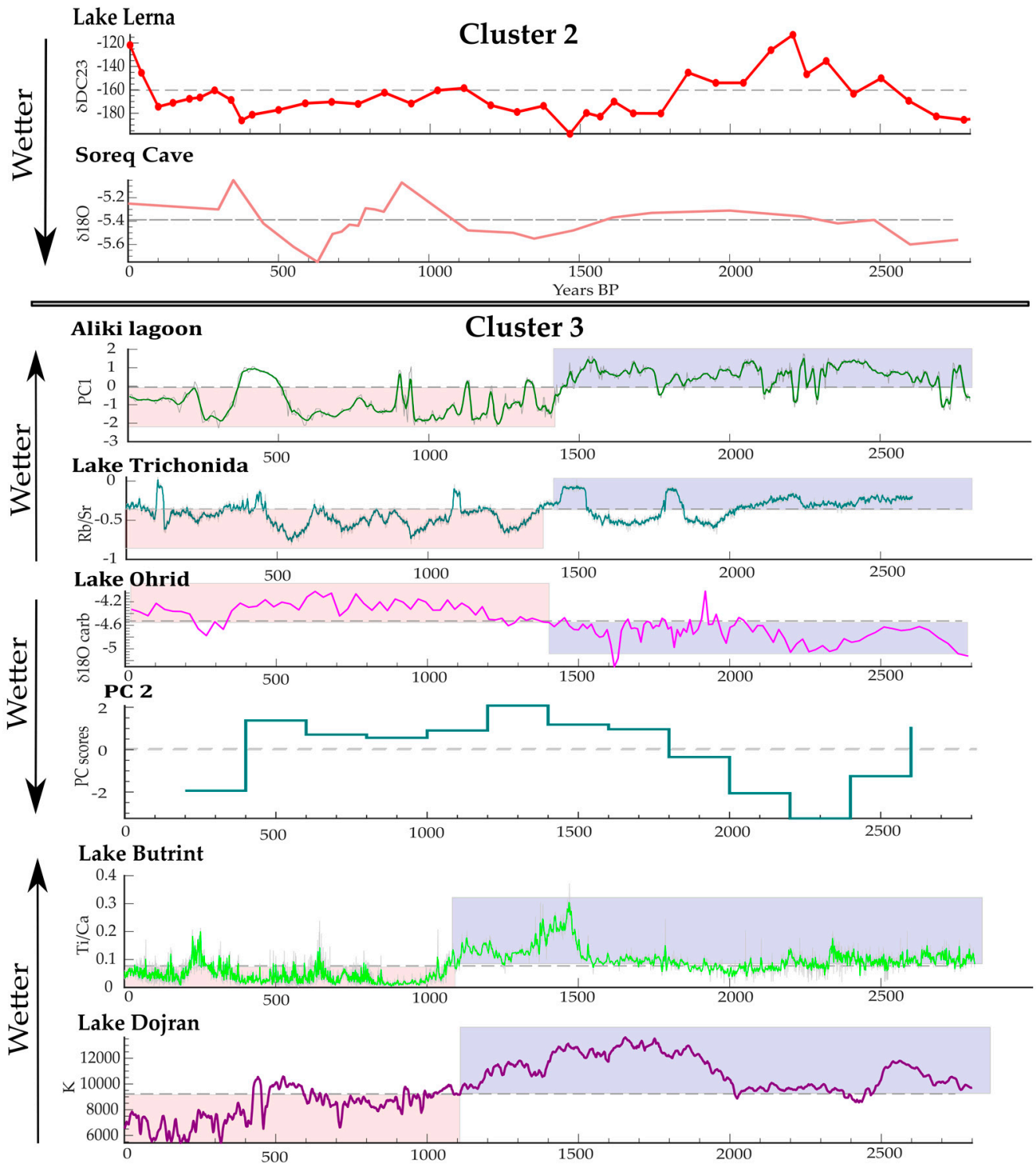

Lake Gölhisar

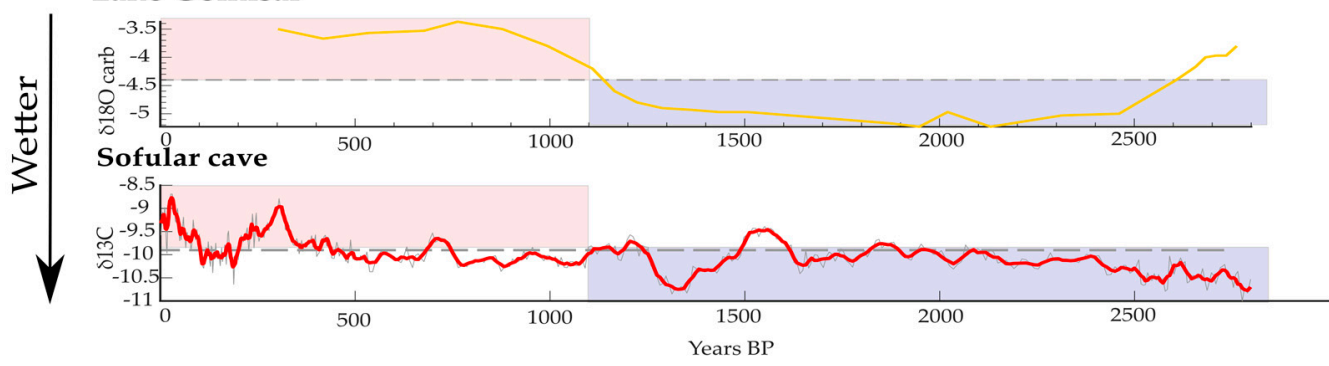

Figure 5. Original proxy records of cluster 2 and cluster 3 .

\section{Conclusions}

In this study, a total of 13 paleoclimatic reconstruction sites were used from the southern Balkans, Turkey, and the Levant to disentangle the paleoclimatic variability of the eastern Mediterranean for the last 2800 years. According to the authors, the proxy best representing palaeohydrological change (wetter/drier conditions) was used from each study. All proxy sequences were filtered to 200-year bins and normalized. Clustering analysis and dimension reduction were implemented in order to identify long-term unifying trends. The study's findings can be summarized as: 
- Two main long-term modes of variability were identified in the studied sites, indicating that no single trajectory of climate variability is evident for the whole eastern Mediterranean.

- A wet to dry millennial trend with a major phase shift at $1400 \mathrm{BP}$ and $1100 \mathrm{BP}$ was identified mainly for the northern and northwestern part of the study area, including the Balkans (except the Peloponnese) and Turkey. A contrasting dry to wet millennialscale with a major phase shift coinciding with the LIA at $750 \mathrm{BP}$ can be extracted for southern Greece and the Levant. This might fit in the overall north-south/east-west seesaw representation of Mediterranean spatial variability.

- Complex interregional variability is evident and widespread at the centennial level throughout the Mediterranean area. Intercluster variability is apparent in all clusters, indicating microclimates or site-specific responses.

- The use of hierarchical clustering analysis and principal component analysis has helped identify long-term unifying trends in dissipating climatic archives.

- The number of sites, incorporating different proxies and different environments, has led to difficulties in short-term correlations, even at a 200-year interval level.

Supplementary Materials: The following are available at https:/ / www.mdpi.com/article/10.3390/ w13223252/s1, Table S1: Transformed z-scores sequences, Figure S1: Maps of the eastern Mediterranean presenting z-scores for each 200-yrs step.

Author Contributions: Conceptualization, D.B., A.E. and P.A.; methodology, D.B.; software, D.B.; validation D.B., A.E. and P.A.; formal analysis, D.B., A.E. and P.A.; investigation, D.B.; resources, P.A.; data curation, D.B.; writing — original draft preparation, D.B.; writing—review and editing, D.B.; visualization, D.B.; supervision, P.A.; project administration, P.A.; funding acquisition, P.A. All authors have read and agreed to the published version of the manuscript.

Funding: This research received no external funding.

Institutional Review Board Statement: Not applicable.

Informed Consent Statement: Not applicable.

Data Availability Statement: The data presented in this study are available on request from the corresponding author.

Acknowledgments: We would like to thank Alexander Francke, Mario Morellón, Faruk Ocakoğlu, Ozan Mert Göktürk, Nadine Quintana Krupinski, Tobias Kluge, Jack H. Lacey, David Psomiadis, Christoph Schwörer, Christos Katrantsiotis, and Neil Roberts for answering our requests and generously providing their data whether or not they were finally included, as well as all the researchers who have made their data publicly available on repositories like NOAA and Pangea.

Conflicts of Interest: The authors declare no conflict of interest.

\section{References}

1. Hoegh-Guldberg, O.; Jacob, D.; Taylor, M.; Bindi, M.; Brown, S.; Camilloni, I.; Diedhiou, A.; Djalante, R.; Ebi, K.L.; Engelbrecht, F.; et al. Impacts of $1.5^{\circ} \mathrm{C}$ Global Warming on Natural and Human Systems. IPCC Special Report on 1.5 Degree Warming Discussing Impact on the Natural and Human Systems Including Health. 2018, pp. 175-311. Available online: https://www.ipcc.ch/site/ assets/uploads/sites/2/2019/02/SR15_Chapter3_Low_Res.pdf (accessed on 16 November 2021).

2. Ji, F.; Wu, Z.; Huang, J.; Chassignet, E.P. Evolution of Land Surface Air Temperature Trend. Nat. Clim. Chang. 2014, 4, 462-466. [CrossRef]

3. Giorgi, F. Climate Change Hot-Spots. Geophys. Res. Lett. 2006, 33, 1-4. [CrossRef]

4. Cramer, W.; Guiot, J.; Fader, M.; Garrabou, J.; Gattuso, J.-P.; Iglesias, A.; Lange, M.A.; Lionello, P.; Llasat, M.C.; Paz, S.; et al. Climate Change and Interconnected Risks to Sustainable Development in the Mediterranean. Nat. Clim. Chang. 2018, 8, 972-980. [CrossRef]

5. Giannakopoulos, C.; Le Sager, P.; Bindi, M.; Moriondo, M.; Kostopoulou, E.; Goodess, C.M. Climatic Changes and Associated Impacts in the Mediterranean Resulting from a $2{ }^{\circ} \mathrm{C}$ Global Warming. Glob. Planet. Chang. 2009, 68, 209-224. [CrossRef]

6. García-Ruiz, J.M.; López-Moreno, I.I.; Vicente-Serrano, S.M.; Lasanta-Martínez, T.; Beguería, S. Mediterranean Water Resources in a Global Change Scenario. Earth-Sci. Rev. 2011, 105, 121-139. [CrossRef] 
7. Lionello, P.; Scarascia, L. The Relation between Climate Change in the Mediterranean Region and Global Warming. Reg. Environ. Chang. 2018, 18, 1481-1493. [CrossRef]

8. Osborn, T.J.; Briffa, K.R. Erratum: The Spatial Extent of 20th-Century Warmth in the Context of the Past 1200 Years (Science (10 Feb) (841)). Science 2006, 312, 697. [CrossRef]

9. Bradley, R.S. Chapter 1-Paleoclimatic Reconstruction, 3rd ed.; Bradley, R.S.B.T.-P., Ed.; Academic Press: San Diego, CA, USA, 2015; pp 1-11, ISBN 978-0-12-386913-5.

10. Finné, M.; Holmgren, K.; Sundqvist, H.S.; Weiberg, E.; Lindblom, M. Climate in the Eastern Mediterranean, and Adjacent Regions, during the Past 6000 Years-A Review. J. Archaeol. Sci. 2011, 38, 3153-3173. [CrossRef]

11. Finné, M.; Woodbridge, J.; Labuhn, I.; Roberts, C.N. Holocene Hydro-Climatic Variability in the Mediterranean: A Synthetic Multi-Proxy Reconstruction. Holocene 2019, 29, 847-863. [CrossRef]

12. Roberts, N.; Moreno, A.; Valero-Garcés, B.L.; Corella, J.P.; Jones, M.; Allcock, S.; Woodbridge, J.; Morellón, M.; Luterbacher, J.; Xoplaki, E.; et al. Palaeolimnological Evidence for an East-West Climate See-Saw in the Mediterranean since AD 900. Glob. Planet. Chang. 2012, 84-85, 23-34. [CrossRef]

13. Dormoy, I.; Peyron, O.; Nebout, N.C.; Goring, S.; Kotthoff, U.; Magny, M.; Pross, J. Terrestrial Climate Variability and Seasonality Changes in the Mediterranean Region between 15,000 and 4000 Years BP Deduced from Marine Pollen Records. Clim. Past 2009, 5, 615-632. [CrossRef]

14. Magny, M.; Peyron, O.; Sadori, L.; Ortu, E.; Zanchetta, G.; Vannière, B.; Tinner, W. Contrasting Patterns of Precipitation Seasonality during the Holocene in the South- and North-Central Mediterranean. J. Quat. Sci. 2012, 27, 290-296. [CrossRef]

15. Jalut, G.; Dedoubat, J.J.; Fontugne, M.; Otto, T. Holocene Circum-Mediterranean Vegetation Changes: Climate Forcing and Human Impact. Quat. Int. 2009, 200, 4-18. [CrossRef]

16. Desprat, S.; Combourieu-Nebout, N.; Essallami, L.; Sicre, M.A.; Dormoy, I.; Peyron, O.; Siani, G.; Bout Roumazeilles, V.; Turon, J.L. Deglacial and Holocene Vegetation and Climatic Changes in the Southern Central Mediterranean from a Direct Land-Sea Correlation. Clim. Past 2013, 9, 767-787. [CrossRef]

17. Shuman, B.N.; Routson, C.; McKay, N.; Fritz, S.; Kaufman, D.; Kirby, M.E.; Nolan, C.; Pederson, G.T.; St-Jacques, J.M. Placing the Common Era in a Holocene Context: Millennial to Centennial Patterns and Trends in the Hydroclimate of North America over the Past 2000 Years. Clim. Past 2018, 14, 665-686. [CrossRef]

18. Kaufman, D.S.; Axford, Y.L.; Henderson, A.C.G.; McKay, N.P.; Oswald, W.W.; Saenger, C.; Anderson, R.S.; Bailey, H.L.; Clegg, B.; Gajewski, K.; et al. Holocene Climate Changes in Eastern Beringia (NW North America)-A Systematic Review of Multi-Proxy Evidence. Quat. Sci. Rev. 2016, 147, 312-339. [CrossRef]

19. Fyfe, R.M.; Woodbridge, J.; Roberts, C.N. Trajectories of Change in Mediterranean Holocene Vegetation through Classification of Pollen Data. Veg. Hist. Archaeobotany 2018, 27, 351-364. [CrossRef]

20. Woodbridge, J.; Roberts, N.; Fyfe, R. Pan-Mediterranean Holocene Vegetation and Land-Cover Dynamics from Synthesized Pollen Data. J. Biogeogr. 2018, 45, 2159-2174. [CrossRef]

21. Katrantsiotis, C.; Kylander, M.E.; Smittenberg, R.; Yamoah, K.K.A.; Hättestrand, M.; Avramidis, P.; Strandberg, N.A.; Norström, E. Eastern Mediterranean Hydroclimate Reconstruction over the Last 3600 Years Based on Sedimentary N-Alkanes, Their Carbon and Hydrogen Isotope Composition and XRF Data from the Gialova Lagoon, SW Greece. Quat. Sci. Rev. 2018, 194, 77-93. [CrossRef]

22. Katrantsiotis, C. Holocene Environmental Changes and Climate Variability in the Eastern Mediterranean: Multiproxy Sediment Records from the Peloponnese Peninsula, SW Greece; Department of Physical Geography, Stockholm University: Stockholm, Sweden, 2019; p. 49.

23. Emmanouilidis, A.; Unkel, I.; Triantaphyllou, M.; Avramidis, P. Late-Holocene Coastal Depositional Environments and Climate Changes in the Gulf of Corinth, Greece. Holocene 2020, 30, 77-89. [CrossRef]

24. Seguin, J.; Avramidis, P.; Dörfler, W.; Emmanouilidis, A.; Unkel, I. A 2600-Year High-Resolution Climate Record from Lake Trichonida (SW Greece). EG Quat. Sci. J. 2020, 69, 139-160. [CrossRef]

25. Morellón, M.; Anselmetti, F.S.; Ariztegui, D.; Brushulli, B.; Sinopoli, G.; Wagner, B.; Sadori, L.; Gilli, A.; Pambuku, A. HumanClimate Interactions in the Central Mediterranean Region during the Last Millennia: The Laminated Record of Lake Butrint (Albania). Quat. Sci. Rev. 2016, 136, 134-152. [CrossRef]

26. Lacey, J.H.; Francke, A.; Leng, M.J.; Vane, C.H.; Wagner, B. A High-Resolution Late Glacial to Holocene Record of Environmental Change in the Mediterranean from Lake Ohrid (Macedonia/Albania). Int. J. Earth Sci. 2015, 104, 1623-1638. [CrossRef]

27. Francke, A.; Wagner, B.; Leng, M.J.; Rethemeyer, J. A Late Glacial to Holocene Record of Environmental Change from Lake Dojran (Macedonia, Greece). Clim. Past 2013, 9, 481-498. [CrossRef]

28. Ocakoğlu, F.; Dönmez, E.O.; Akbulut, A.; Tunoğlu, C.; Kır, O.; Açıkalın, S.; Erayık, C.; Yılmaz, İ.Ö.; Leroy, S.A.G. A 2800-Year Multi-Proxy Sedimentary Record of Climate Change from Lake Çubuk (Göynük, Bolu, NW Anatolia). Holocene 2016, $26,205-221$. [CrossRef]

29. Fleitmann, D.; Cheng, H.; Badertscher, S.; Edwards, R.L.; Mudelsee, M.; Göktürk, O.M.; Fankhauser, A.; Pickering, R.; Raible, C.C.; Matter, A.; et al. Timing and Climatic Impact of Greenland Interstadials Recorded in Stalagmites from Northern Turkey. Geophys. Res. Lett. 2009, 36, 1-5. [CrossRef]

30. Eastwood, W.J.; Leng, M.J.; Roberts, N.; Davis, B. Holocene Climate Change in the Eastern Mediterranean Region: A Comparison of Stable Isotope and Pollen Data from Lake Gölhisar, Southwest Turkey. J. Quat. Sci. 2007, 22, 327-341. [CrossRef] 
31. Roberts, N.; Jones, M.D.; Benkaddour, A.; Eastwood, W.J.; Filippi, M.L.; Frogley, M.R.; Lamb, H.F.; Leng, M.J.; Reed, J.M.; Stein, M.; et al. Stable Isotope Records of Late Quaternary Climate and Hydrology from Mediterranean Lakes: The ISOMED Synthesis. Quat. Sci. Rev. 2008, 27, 2426-2441. [CrossRef]

32. Cheng, H.; Sinha, A.; Verheyden, S.; Nader, F.H.; Li, X.L.; Zhang, P.Z.; Yin, J.J.; Yi, L.; Peng, Y.B.; Rao, Z.G.; et al. The Climate Variability in Northern Levant over the Past 20,000 Years. Geophys. Res. Lett. 2015, 42, 8641-8650. [CrossRef]

33. Quintana Krupinski, N.B.; Marlon, J.R.; Nishri, A.; Street, J.H.; Paytan, A. Climatic and Human Controls on the Late Holocene Fire History of Northern Israel. Quat. Res. 2013, 80, 396-405. [CrossRef]

34. Bar-Matthews, M.; Ayalon, A.; Gilmour, M.; Matthews, A.; Hawkesworth, C.J. Sea-Land Oxygen Isotopic Relationships from Planktonic Foraminifera and Speleothems in the Eastern Mediterranean Region and Their Implication for Paleorainfall during Interglacial Intervals. Geochim. Et Cosmochim. Acta 2003, 67, 3181-3199. [CrossRef]

35. Bar-Matthews, M.; Ayalon, A.; Kaufman, A. Late Quaternary Paleoclimate in the Eastern Mediterranean Region from Stable Isotope Analysis of Speleothems at Soreq Cave, Israel. Quat. Res. 1997, 47, 155-168. [CrossRef]

36. Bar-Matthews, M.; Ayalon, A.; Kaufman, A.; Wasserburg, G.J. The Eastern Mediterranean Paleoclimate as a Reflection of Regional Events: Soreq Cave, Israel. Earth Planet. Sci. Lett. 1999, 166, 85-95. [CrossRef]

37. Ülgen, U.B.; Franz, S.O.; Biltekin, D.; Çagatay, M.N.; Roeser, P.A.; Doner, L.; Thein, J. Climatic and Environmental Evolution of Lake Iznik (NW Turkey) over the Last 4700 Years. Quat. Int. 2012, 274, 88-101. [CrossRef]

38. Kutiel, H.; Benaroch, Y. North Sea-Caspian Pattern (NCP)—An Upper Level Atmospheric Teleconnection Affecting the Eastern Mediterranean: Identification and Definition. Theor. Appl. Climatol. 2002, 71, 17-28. [CrossRef]

39. Nastos, P.T.; Philandras, C.M.; Founda, D.; Zerefos, C.S. Air Temperature Trends Related to Changes in Atmospheric Circulation in the Wider Area of Greece. Int. J. Remote Sens. 2011, 32, 737-750. [CrossRef] 